\title{
THE IMPACT OF MINERAL FERTILIZATION AND ATMOSPHERIC PRECIPITATION ON YIELD OF FIELD CROPS ON FAMILY FARMS ${ }^{1}$
}

\author{
Mihajlo Munćan ${ }^{2}$
}

\section{Summary}

The field crop production, as the most important branch of plant production of the Republic of Serbia, in the period 2002-2011, was carried out on an average of over 2.7 million hectares, 82.7\% of which took place on the individual farms/family holdings. Hence, the subject of research in this paper covers yields of major field crops realized on family farms in the region of Vojvodina in the period 1972-2011. The main objective of the research is to study the interdependence of utilization of mineral fertilizers and atmospheric precipitation during the vegetation period and realized yields of major field crops on family farms in the observed period. The regression analysis was applied in order to verify dependencies and determine the form of dependence of achieved yields from examined variables. The results showed that the main limiting factors for obtaining high and stable yields of field crops is inadequate use of fertilizers and the lack of precipitation during the vegetation period.

Key words: interdependence, mineral fertilizers, atmospheric precipitation, field crop, family farm

JEL: Q15, C35

\section{Introduction}

Field crop production, as the most important branch of plant production in Serbia, in the period 2002-2011, was carried out on an average of over 2.7 million hectares per year, while its share in the value structure of the total agricultural production in the reporting period ranged from $46.8 \%$ to $59.2 \%$. The field crop production of the Republic of Serbia is mostly realized on the territory of Vojvodina region. This area on average comprises about $52 \%$ of the total area under grains and over $92 \%$ of the total area under industrial plants (Bošnjak, Rodić, 2010). Family farms are the most important carriers of organized agricultural production in Vojvodina.

1 Paper represents a part of the research on the project ,Serbian Rural Labour Market and Rural Economics - Revenue Diversification and Poverty Mitigation”, No. ON179028, financially supported by the Ministry of Education, Science and Technological Development of the Republic of Serbia

2 Mihajlo Munćan, Ph.D., Assistant professor, University of Belgrade, Faculty of Agriculture, Nemanjina Street no. 6, 11080 Zemun, Serbia, Phone: +381 11 4413406, E-mail: mmuncan@agrif.bg.ac.rs

EP 2016 (63) 3 (817-833) 
In the conditions of modern (conventional) agricultural production, the realized yields are under decisive impact of the adequate application of agro-technical measures/agricultural practices (fertilization, irrigation, new varieties and hybrids, the use of plant protection products, modern means of mechanization, etc.). However, not all of the agricultural practices exert the equal impact on yields. The mineral fertilizers are particularly important, as confirmed by the results of numerous studies and assessments by FAO showing that the use of fertilizers contributes with 50\% to the increase of yields (Kresović, 2010). From the above it can be concluded that the mineral fertilizers represent a powerful tool in increasing yields with high impact on the level of intensity of production. In addition to mineral fertilization, the atmospheric precipitation is the main source of water for the land, and thus for the plants. The precipitation is necessary for plants throughout the growing season, but there is a period of particular sensitivity to the water deficit in the development of the plant. The precipitation is of the greatest significance during the vegetation period. These two production factors have had a decisive impact on the level of realized yields of major field crops in the period 2002-2011, characterized by significant annual variations in the realized yields as well as in the total volume of plant production. The realized yields of main field crops - wheat, maize, sunflower, soybean and sugar beet, during the mentioned period, on average, were $3.57 \mathrm{t} / \mathrm{ha}, 5.12 \mathrm{t} / \mathrm{ha}, 2.18 \mathrm{t} / \mathrm{ha}, 2.52 \mathrm{t} / \mathrm{ha}$ and $41.99 \mathrm{t} / \mathrm{ha}$, respectively, and were lower on average by $50 \%$ compared to the yields achieved in highly developed European countries (France, Germany, the Netherlands).

\section{The subject and objective of the study}

On the basis of above presented facts and results, the analysis of realized yields of major field crops on family farms in the region of Vojvodina in the period 1972-2011 was set as the subject of the research in the present study. Given the importance of the subject of research, the following objectives were formulated:

- Analysis of the sowing structure, realized yields and utilization of mineral fertilizers in the production of major field crops on family farms, and the amount of precipitation during the vegetation period in the Vojvodina region in the period 1972-2011;

- Examination of the interdependence of utilization of mineral fertilizers and atmospheric precipitation during the vegetation period and realized yields of major field crops on family farms in the period 1972-2011.

\section{Data sources and method of the study}

The data from multiple sources were used in the realization of the set tasks. Data on the variations in the structure of field crop production, realized yields and utilization of mineral fertilizers on family farms in the region of Vojvodina in the period 1971-2001, were taken from the statistical bulletins "Field crop production, fruit production and viticulture", published in 2001 by the Federal Bureau of Statistics. Since the Statistical Office of the Republic of Serbia does not observe/monitor the information of interest for the present study, or publishes the relevant bulletin, the data for the period 2002-2011 on the structure of field crop production 
and the realized yields on family farms in Vojvodina were taken from the documentary materials of the Statistical Office of the Republic of Serbia, and data on utilization of mineral fertilizers from FAO base. Data on the atmospheric precipitation in Vojvodina, in the period 1972-2011, were taken from the documentation of the Hydro meteorological Service of the Republic of Serbia.

The relative indicators of dynamics, i.e. base indices and average growth rates were used in the analysis of the situation and variations of the phenomenon. Data analysis was performed using the analytical statistics with the help of statistical package IBMSPSS statistics 17.0. First, the indicators of the descriptive statistics were calculated to obtain a general trend of the variability of the crop production structure, yields and utilization of mineral fertilizers on family farms and precipitation in the observed forty-year period (1972-2011) in Vojvodina. Relative dependence was measured using the Pearson's correlation coefficients, tested at a significance level of $5 \%$ and $1 \%$.

\section{The research results}

The observed forty-year period of research (1972-2011) was divided into four ten-year subperiods, as follows: from 1972 to 1981; 1982 to1991; 1992 to 2001 and 2002 to 2011. In order to determine the basic characteristics of the observed phenomena for individual sub-period and the observed period in its entirety, the following statistical indicators were calculated: mean value, interval of variation, coefficient of variation and rate of change.

\section{The trends in the structure of field crop production}

In the structure of field crop production in Vojvodina, the most common are two groups of crops: the grains/cereals, with dominant wheat and maize, and industrial plants, with the most common crops - sunflower, soybean and sugar beet. The average share of the grains/cereals in the structure of sowing on family farms in the period 1972-2011 was $67.81 \%$ (Table 1).

Table 1. The share of grain in the structure of used arable land on family farms in Vojvodina, in the period 1972-2011

\begin{tabular}{|c|c|c|c|c|c|}
\hline \multirow{2}{*}{ Period } & \multirow{2}{*}{$\begin{array}{c}\text { Mean } \\
\text { value }\end{array}$} & \multirow{2}{*}{$\begin{array}{c}\text { Coefficient of } \\
\text { variation (Cv) }\end{array}$} & \multicolumn{2}{|c|}{ Interval of variation } & \multirow{2}{*}{$\begin{array}{c}\text { Rate of } \\
\text { change }\end{array}$} \\
\cline { 4 - 5 } & \multicolumn{7}{|c|}{ Wheat } \\
\hline $1972-1981$ & 15.85 & 12.57 & 13.44 & 19.24 & -3.50 \\
\hline $1982-1991$ & 16.48 & 18.62 & 10.38 & 20.80 & 1.69 \\
\hline $1992-2001$ & 18.19 & 17.27 & 11.50 & 22.38 & 6.03 \\
\hline $2002-2011$ & 15.74 & 15.07 & 13.14 & 21.21 & -4.78 \\
\hline $\mathbf{1 9 7 2 - 2 0 1 1}$ & $\mathbf{1 6 . 5 7}$ & $\mathbf{1 7 . 2 7}$ & $\mathbf{1 0 . 3 8}$ & $\mathbf{2 2 . 3 8}$ & $\mathbf{- 0 . 8 8}$ \\
\hline \multicolumn{7}{|l|}{ Maize } \\
\hline $1972-1981$ & 49.92 & 6.57 & 43.75 & 53.54 & -0.21 \\
\hline $1982-1991$ & 55.79 & 5.26 & 52.02 & 60.66 & -0.74 \\
\hline $1992-2001$ & 50.94 & 6.35 & 45.61 & 58.89 & -2.05 \\
\hline $2002-2011$ & 48.32 & 2.42 & 47.07 & 50.71 & 0.63 \\
\hline
\end{tabular}




\begin{tabular}{|c|c|c|c|c|c|}
\hline \multirow{2}{*}{ Period } & \multirow{2}{*}{$\begin{array}{c}\text { Mean } \\
\text { value }\end{array}$} & \multirow{2}{*}{$\begin{array}{c}\text { Coefficient of } \\
\text { variation }(\mathrm{Cv})\end{array}$} & \multicolumn{2}{|c|}{ Interval of variation } & \multirow{2}{*}{$\begin{array}{c}\text { Rate of } \\
\text { change }\end{array}$} \\
\cline { 4 - 5 } & & $\mathbf{M i n}$ & Max & -0.18 \\
\hline $1972-2011$ & $\mathbf{5 1 . 2 4}$ & $\mathbf{7 . 7 0}$ & $\mathbf{4 3 . 7 5}$ & $\mathbf{6 0 . 6 6}$ & $\mathbf{0}$ \\
\hline
\end{tabular}

Source: Author's calculations based on data from the bulletin "The field crop production, fruit production and viticulture" and documentary material, the Statistical office of the Republic of Serbia, Belgrade.

The share of industrial plants in the structure of sowing of arable land on family farms was on average $11.89 \%$ (Table 2 ).

Table 2. The share of industrial plants in the structure of used arable land on family farms in Vojvodina, in the period 1972-2011

\begin{tabular}{|c|c|c|c|c|c|}
\hline \multirow{2}{*}{ Period } & \multirow{2}{*}{$\begin{array}{l}\text { Mean } \\
\text { value }\end{array}$} & \multirow{2}{*}{$\begin{array}{l}\text { Coefficient of } \\
\text { variation }(\mathrm{Cv})\end{array}$} & \multicolumn{2}{|c|}{ Interval of variation } & \multirow{2}{*}{$\begin{array}{l}\text { Rate of } \\
\text { change }\end{array}$} \\
\hline & & & Min & Max & \\
\hline \multicolumn{6}{|c|}{ Sunflower } \\
\hline $1972-1981$ & 7.20 & 24.04 & 5.28 & 10.51 & 0.70 \\
\hline 1982-1991 & 4.13 & 56.96 & 0.51 & 7.96 & 8.84 \\
\hline $1992-2001$ & 7.21 & 29.86 & 1.23 & 9.58 & -0.14 \\
\hline $2002-2011$ & 10.09 & 6.31 & 9.23 & 11.01 & 1.03 \\
\hline 1972-2011 & 7.16 & 39.11 & 0.51 & 11.01 & 1.71 \\
\hline \multicolumn{6}{|c|}{ Soybean } \\
\hline $1972-1981$ & 0.15 & 83.09 & 0.00 & 0.31 & 80.57 \\
\hline $1982-1991$ & 1.00 & 31.69 & 0.43 & 1.44 & -5.83 \\
\hline $1992-2001$ & 2.20 & 67.26 & 0.91 & 5.88 & 8.46 \\
\hline $2002-2011$ & 6.78 & 19.74 & 5.03 & 8.93 & 6.20 \\
\hline 1972-2011 & 2.53 & 108.74 & 0.00 & 8.39 & 24.98 \\
\hline \multicolumn{6}{|c|}{ Sugar beet } \\
\hline $1972-1981$ & 2.18 & 15.40 & 1.53 & 2.58 & 3.73 \\
\hline 1982-1991 & 2.49 & 28.52 & 1.66 & 3.81 & 4.17 \\
\hline $1992-2001$ & 1.74 & 20.99 & 1.31 & 2.61 & -6.32 \\
\hline $2002-2011$ & 2.41 & 15.28 & 1.59 & 3.04 & -0.84 \\
\hline 1972-2011 & 2.20 & 25.11 & 1.31 & 3.81 & 0.79 \\
\hline
\end{tabular}

Source: Author's calculations based on data from the bulletin "The field crop production, fruit production and viticulture" and documentary material, the Statistical office of the Republic of Serbia, Belgrade.

\section{The realized yields of major field crops}

During the forty-year period, the average yield of wheat was $3.86 \mathrm{t} / \mathrm{ha}$, showing a tendency of increase (Table 3). At the beginning of the observed period, the yield of wheat exhibited a tendency of increase at an average annual rate of $4.48 \%$, and in the second sub-period it reached the highest observed value of $4.62 \mathrm{t} /$ ha while retaining still the growth rate of $2.23 \%$. The nineties of the last century, i.e. the third observed sub-period, were marked by great economic crisis (caused by UN sanctions and the war in the former Yugoslavia) that had a great impact on the total agricultural production, and therefore the production of 
wheat. In fact, during this period the lowest average yields of wheat in the whole observed period were recorded.

The average maize yield in the reporting period was $5.04 \mathrm{t} / \mathrm{ha}$ and ranged from a minimum of $3.31 \mathrm{t} / \mathrm{ha}$, to a maximum of $6.83 \mathrm{t} / \mathrm{ha}$. The yield of maize in the entire observed period was accompanied by a significant variation $(\mathrm{Cv}=19.67)$ with the manifestation of the tendency of slight increase at an average annual rate of $0.69 \%$. As in wheat production, in the third analysed sub-period, the lowest average yields of maize were realized, only 4,09 t/ha, as a result of the reduced level of intensity of production caused by the economic crisis which marked that period.

Table 3. The realized yields of wheat on family farms in Vojvodina in the period from 1972 to 2011

\begin{tabular}{|c|c|c|c|c|c|}
\hline \multirow{2}{*}{ Period } & \multirow{2}{*}{ Mean value } & \multirow{2}{*}{$\begin{array}{l}\text { Coefficient of } \\
\text { variation }(\mathrm{Cv})\end{array}$} & \multicolumn{2}{|c|}{ Interval of variation } & \multirow{2}{*}{$\begin{array}{l}\text { Rate of } \\
\text { change }\end{array}$} \\
\hline & & & Min & Max & \\
\hline \multicolumn{6}{|c|}{ Wheat } \\
\hline $1972-1981$ & 3.75 & 15.30 & 2.69 & 4.75 & 4.48 \\
\hline $1982-1991$ & 4.62 & 7.30 & 4.19 & 5.22 & 2.23 \\
\hline $1992-2001$ & 3.52 & 11.42 & 2.77 & 3.96 & 3.29 \\
\hline $2002-2011$ & 3.57 & 16.38 & 2.09 & 4.36 & 3.50 \\
\hline 1972-2011 & 3.86 & 17.07 & 2.09 & 5.22 & 1.25 \\
\hline \multicolumn{6}{|c|}{ Maize } \\
\hline $1972-1981$ & 5.37 & 10.13 & 4.42 & 6.18 & 2.95 \\
\hline $1982-1991$ & 5.57 & 19.62 & 3.62 & 6.83 & 0.36 \\
\hline $1992-2001$ & 4.09 & 14.91 & 3.31 & 5.47 & 5.74 \\
\hline $2002-2011$ & 5.12 & 17.16 & 3.34 & 6.18 & 1.81 \\
\hline 1972-2011 & 5.04 & 19.67 & 3.31 & 6.83 & 0.69 \\
\hline
\end{tabular}

Source: Author's calculations based on data from the bulletin "The field crop production, fruit production and viticulture" and documentary material, the Statistical office of the Republic of Serbia, Belgrade.

Unlike wheat and maize, the highest sunflower and soybean yields were achieved in the fourth sub-period and the highest yield of sugar beet in the second sub-period (Table 4).

Table 4. The realized yields of industrial crops on family farms in Vojvodina in the period 1972-2011

\begin{tabular}{|c|c|c|c|c|c|}
\hline \multirow{2}{*}{ Period } & \multirow{2}{*}{ Mean value } & $\begin{array}{c}\text { Coefficient of variation } \\
(\mathbf{C v}) \\
\text { Min }\end{array}$ & \multicolumn{2}{|c|}{ Interval of variation } & \multirow{2}{*}{$\begin{array}{c}\text { Rate of } \\
\text { change }\end{array}$} \\
\cline { 3 - 6 } & \multicolumn{5}{|c|}{ Sunflower } \\
\hline $1972-1981$ & 1.82 & 21.96 & 1.39 & 2.49 & -0.14 \\
\hline $1982-1991$ & 2.08 & 16.22 & 1.31 & 2.60 & 6.04 \\
\hline $1992-2001$ & 1.76 & 13.35 & 1.32 & 2.11 & 1.11 \\
\hline $2002-2011$ & 2.18 & 11.39 & 1.83 & 2.48 & 2.44 \\
\hline $\mathbf{1 9 7 2 - 2 0 1 1}$ & $\mathbf{1 . 9 6}$ & $\mathbf{1 8 . 2 6}$ & $\mathbf{1 . 3 1}$ & $\mathbf{2 . 6 0}$ & $\mathbf{1 . 0 9}$ \\
\hline
\end{tabular}




\begin{tabular}{|c|c|c|c|c|c|}
\hline \multirow[b]{2}{*}{ Period } & \multirow[b]{2}{*}{ Mean value } & \multirow{2}{*}{$\begin{array}{c}\text { Coefficient of variation } \\
\text { (Cv) } \\
\text { Min }\end{array}$} & \multicolumn{2}{|c|}{ Interval of variation } & \multirow{2}{*}{$\begin{array}{l}\text { Rate of } \\
\text { change }\end{array}$} \\
\hline & & & $\operatorname{Max}$ & & \\
\hline \multicolumn{6}{|c|}{ Soybeat } \\
\hline $1972-1981$ & 1. & 31.89 & 0.52 & 2.34 & 1.36 \\
\hline $1982-1991$ & 2. & 18.05 & 1.53 & 2.53 & 0.36 \\
\hline $1992-2001$ & 1. & 25.30 & 1.24 & 2.66 & 7.62 \\
\hline $2002-2011$ & 2.3 & 15.08 & 1.73 & 3.11 & 0.60 \\
\hline 1972-2011 & 2.1 & 26.77 & 0.52 & 3.11 & 1.13 \\
\hline \multicolumn{6}{|c|}{ Sugar beet } \\
\hline $1972-1981$ & 39. & 11.69 & 28.52 & 43.72 & 2.59 \\
\hline $1982-1991$ & 42. & 10.79 & 34.70 & 48.86 & 1.49 \\
\hline $1992-2001$ & 34. & 17.16 & 23.54 & 42.39 & 2.83 \\
\hline $2002-2011$ & 41. & 14.24 & 28.40 & 47.64 & 3.19 \\
\hline 1972-2011 & 39. & 15.65 & 23.54 & 48.86 & 0.75 \\
\hline
\end{tabular}

Source: Author's calculations based on data from the bulletin "The field crop production, fruit production and viticulture" and documentary material, the Statistical office of the Republic of Serbia, Belgrade.

\section{The trends in the utilization of mineral fertilizers}

The utilization of mineral fertilizers is expressed as the average utilization in kilograms per unit of surface area, for the entire period and by individual sub-period (Table 5).

Table 5. The utilization of mineral fertilizers on family farms in Vojvodina in the period 1972-2011

\begin{tabular}{|c|c|c|c|c|c|}
\hline \multirow{2}{*}{ Period } & \multirow{2}{*}{ Mean value } & \multirow{2}{*}{$\begin{array}{c}\text { Coefficient of } \\
\text { variation (Cv) }\end{array}$} & \multicolumn{2}{|c|}{ Interval of variation } & \multirow{2}{*}{$\begin{array}{c}\text { Rate of } \\
\text { change }\end{array}$} \\
\cline { 4 - 5 } & & 20.23 & 256 & 465 & 5.80 \\
\hline $1972-1981$ & 344.60 & 11.13 & 323 & 474 & -3.19 \\
\hline $1982-1991$ & 417.10 & 47.01 & 26 & 122 & -4.58 \\
\hline $1992-2001$ & 56.50 & 16.10 & 87 & 153 & 6.24 \\
\hline $2002-2011$ & 130.00 & $\mathbf{6 5 . 3}$ & $\mathbf{2 6}$ & $\mathbf{4 7 6}$ & $\mathbf{- 1 . 5 9}$ \\
\hline $\mathbf{1 9 7 2 - 2 0 1 1}$ & $\mathbf{2 3 4 . 5 5}$ & &
\end{tabular}

Source: Author's calculations based on data from the bulletin "The field crop production, fruit production and viticulture" and documentary material, the Statistical office of the Republic of Serbia, Belgrade.

At the beginning of the analysed forty-year period, the utilization of mineral fertilizers exhibited a tendency of increase at an average annual rate of $5.80 \%$, to reach the highest average value of $417.10 \mathrm{~kg} / \mathrm{ha}$ in the second observed sub-period. In the third sub-period (1992-2001), the greatest variation in the utilization of mineral fertilizers ( $\mathrm{Cv}$ 47.01) was registered and the average utilization was only $56.5 \mathrm{~kg} / \mathrm{ha}$. It is in this period that the greatest decrease in the utilization of mineral fertilizers at a rate of $-4.58 \%$ a year on average is recorded. These trends in the utilization of mineral fertilizers were results of the great economic crisis in Serbia, which marked the nineties of the last century. A significant drop in the utilization 
of mineral fertilizers in this sub-period is caused, on the one hand by reducing the intensity of agricultural production imposed by the worsening economic position of family farms, and on the other, by the high prices of mineral fertilizers because of the relatively small domestic production, importer monopoly and disturbed relationships in the market. Although in the last, fourth sub-period, the utilization of mineral fertilizers exhibited a tendency of increase (6.24\%), the level of average realized utilization was by about 2.5 times lower compared to the level achieved in the initial period of analysis (1972-1981) and approximately by 3.2 times compared to the level achieved in the second sub-period. Compared to the average utilization of mineral fertilizers in the EU-27 in the period 2002-2011, the utilization of mineral fertilizers in Serbia is lower by more than $25 \%$. Compared with individual EU-27 member States, it is observed that Ireland has the highest utilization, 3.3 times higher than Serbia, followed by The Netherlands 2.2 times, Croatia 1.73 and Great Britain 1.4 times. Somewhat lower utilization of mineral fertilizers in relation to Serbia is recorded for Estonia, Lithuania, Latvia, Malta and Romania.

\section{The amount and distribution of atmospheric precipitation}

The water deficit in the area of Vojvodina was especially pronounced in the summer months of July, August and September, when the air temperature was high, relative humidity at a minimum, and evapotranspiration very high. Presumably, $60 \%$ or about $362 \mathrm{~mm}$ of the average annual rainfall in Vojvodina comes in spring and summer (April-September), and considering that the total water requirements of field crops during the vegetation period, according to findings from several authors (Bojović, 2014; Glamočlija, 2004; Maksimović, Dragović, 2002; Pejić, 2008; Tabaković, 2012) are as follows: wheat, about $200 \mathrm{~mm}$, maize 430-510, sunflower 300-400 mm, soybean 380-545 and sugar beet $560 \mathrm{~mm}$, it can be concluded that the production of field crops in Vojvodina is certainly facing water shortage/deficit.

The analysis of atmospheric precipitation in Vojvodina shows that in the period 1972- 2011, there were 11 years with the annual sum of precipitation below $500 \mathrm{~mm}, 6$ years with the annual sum of precipitation of $500-550 \mathrm{~mm}$ and 4 years below $600 \mathrm{~mm}$ (Table 6). If it is taken into consideration that the total water requirements of field crops in this area are as follows: wheat 320-360 mm, maize 450-530 mm, sunflower about $450 \mathrm{~mm}$, soybean 450$480 \mathrm{~mm}$ and sugar beet 550-560 mm (Pejić, 2008), it can be concluded that the production of maize, sugar beet and especially soybeans is mostly endangered by the water deficit.

Table 6. The amount and distribution of precipitation in Vojvodina in the period 1972 to 2011

\begin{tabular}{|c|c|c|c|c|}
\hline \multirow{2}{*}{ Period } & \multirow{2}{*}{ Mean value } & Coefficient of & \multicolumn{2}{|c|}{ Interval of variation } \\
\cline { 4 - 5 } & & \multicolumn{4}{|c|}{ variation (Cv) } & Min & Max \\
\hline \multicolumn{5}{|c|}{ Total } \\
\hline $1972-1981$ & 630.77 & 9.33 & 496.57 & 711.14 \\
\hline $1982-1991$ & 549.17 & 14.06 & 441.14 & 687.20 \\
\hline $1992-2001$ & 609.83 & 26.51 & 277.06 & 854.81 \\
\hline $2002-2011$ & 669.43 & 26.30 & 412.67 & 940.39 \\
\hline $\mathbf{1 9 7 2 - 2 0 1 1}$ & $\mathbf{6 0 4 . 6 2}$ & $\mathbf{2 2 . 1 4}$ & $\mathbf{2 7 7 . 0 6}$ & $\mathbf{9 4 0 . 3 9}$ \\
\hline
\end{tabular}




\begin{tabular}{|c|c|c|c|c|}
\hline \multirow{2}{*}{ Period } & \multirow{2}{*}{ Mean value } & Coefficient of & \multicolumn{2}{|c|}{ Interval of variation } \\
\cline { 3 - 5 } & & \multicolumn{4}{|c|}{ Variation (Cv) } & Min & Max \\
\hline \multicolumn{5}{|c|}{ Vegetation period } \\
\hline $1972-1981$ & 387.69 & 14.17 & 309.29 & 509.00 \\
\hline $1982-1991$ & 328.97 & 18.73 & 242.43 & 430.96 \\
\hline $1992-2001$ & 366.16 & 35.29 & 143.59 & 596.99 \\
\hline $2002-2011$ & 394.06 & 34.52 & 234.60 & 605.29 \\
\hline $\mathbf{1 9 7 2 - 2 0 1 1}$ & $\mathbf{3 6 1 . 9 0}$ & $\mathbf{2 8 . 6 0}$ & $\mathbf{1 4 3 . 5 9}$ & $\mathbf{6 0 5 . 2 9}$ \\
\hline
\end{tabular}

Source: Source: Author's calculations based on data of Republic Hydrometeorological Service of Serbia.

Periodic droughts, as they occurred in 1973, 1983, 1988, 1990, 1993, 2000, and 2002, inflict great damage to agriculture. According to the Statistical Office of the Republic of Serbia, in Vojvodina, in year 2003, which was very dry, the average yields of wheat, maize, sunflower, soybean and sugar beet were $2.01 \mathrm{t}, 3.34,1.82,1.52$ and $28.49 \mathrm{t} / \mathrm{ha}$, respectively. In extremely dry year 2000, which was characterized by the lowest annual total precipitation of only 277 $\mathrm{mm}$, of which only $143 \mathrm{~mm}$ recorded during the vegetation period, the realized average yields of wheat, maize, sunflower, soybean and sugar beet were very low: 2.98, 2.82, 1.42, 1.15 and $22.54 \mathrm{t} / \mathrm{ha}$, respectively.

\section{The correlation - regression analysis}

The regression analysis is applied in order to verify dependencies and determine the form of dependences between achieved yields and the examined variables: the quantity of used mineral fertilizers and atmospheric precipitation during the vegetation period. The regression analysis is one of the most commonly used statistical techniques, which has found a wide application in the most diverse areas of research. Formally, it is a model that represents a powerful and flexible procedure for the analysis of the connection/correlation between the metric dependent variable and one or more independent variables, which are usually measured also on the metric scale.

Considering that the impact of two independent variables (quantity of used mineral fertilizers and atmospheric precipitation during the vegetation period) on the realized yields of major field crops is investigated, the models of standard multiple (Multiple) linear regression are defined.

$$
Y=\beta_{0}+\beta_{1} x_{1}+\beta_{2} x_{2}+\cdots+\beta_{n} x_{n}+\varepsilon
$$

where:

$Y$ - independent variable

$x_{1}, x_{2}, \ldots x_{n}-$ independent variables

$\beta_{0}$ - constant (intercept)

$\beta_{1}, \beta_{2}, \ldots . \beta_{n}-$ coefficients of independent variables

The significance of the impact of all key parameters of regression models that have investigated 
the influence of the quantity of used mineral fertilizers and atmospheric precipitation during the vegetation period on the yields of major field crops on family farms was evaluated for the risk level of $5 \%$ and $1 \%$.

\section{The analysis of yield of wheat}

\section{Wheat $=3041.39+2.543$ mineral fertilizers +0.614 precipitation}

Based on the estimated equation and obtained related statistical indicators, it can be concluded that the observed factors (mineral fertilizers and atmospheric precipitation during the vegetation period) contributed to changes in the realized yields of wheat with $R^{2}=34.1 \%$. However, the standardized values of beta $(\beta)$ coefficients are used in order to examine more accurately the impact of these factors on the yield of wheat, because the analysed values are expressed in different units, and these coefficients do not depend on the units of measurement of variables.

Table 7. The regression of the amount of used mineral fertilizers and atmospheric precipitation during the vegetation period on wheat yield

\begin{tabular}{|c|c|c|c|c|c|}
\hline \multirow[t]{2}{*}{$\mathrm{N}=40$} & \multicolumn{5}{|c|}{$\begin{array}{l}\text { Regression Summary for Dependent Variable: Yield of } \\
\text { wheat } \\
\mathrm{R}=0.584 \\
\mathrm{R} \text { Square }=0.341 \\
\text { Adjusted } \mathrm{R} \text { Square }=0.305 \\
\mathrm{~F}=9.553 \text { (Sig. }=0.000 \text { ) } \\
\text { Std. } \text { Error of the Estimate }=556.860 \\
\end{array}$} \\
\hline & $\mathrm{B}$ & Std. Error & Beta & $\mathrm{t}$ & Sig. \\
\hline Constant & 3041.399 & 369.701 & & 8.227 & 0.000 \\
\hline Used mineral fertilizers & 2.543 & 0.582 & 0.591 & 4.371 & 0.000 \\
\hline $\begin{array}{l}\text { Atmospheric precipitation during the } \\
\text { vegetation period }\end{array}$ & 0.614 & 0.844 & 0.098 & 0.727 & 0.472 \\
\hline
\end{tabular}

Source: Author's calculations

The used mineral fertilizers have higher value of beta coefficient $(\beta=0.591)$, while the atmospheric precipitation during the vegetation period showed much lower value $(\beta=$ 0.098). Obtained values of beta coefficients show that mineral fertilizers had more significant impact on the amount of realized yields of wheat than the amount of precipitation during the vegetation period. The connection/correlation between the yield and used mineral fertilizers is statistically highly significant $(p<0.01)$, i.e. this variable significantly contributed to the prediction of the dependent variable. The second independent variable, atmospheric precipitation during the vegetation period, exerted no statistically significant effect on the amount of wheat yields ( $>00.05$ ). In addition, the regression model in its entirety indicates statistical significance because the $F$ - ratio $=9.553$ is rated as very significant $(p<0.01)$. 


\section{The analysis of yield of maize}

\section{Maize $=2486.872+4.188$ mineral fertilizers +4.234 precipitation}

The yield of maize can be explained by the estimated regression model with $R^{2}=56.7 \%$ while the strength of connection/correlation between observed variables is $R=0.753$. The influence of independent variables on the yield of maize is positive and statistically highly significant and both in the case of used mineral fertilizers $(\beta=0.668, \mathrm{p}<0.01)$ and the precipitation during the vegetation period $(\beta=0.446, p<0.01)$. This regression model in its entirety indicates statistical significance because the F-ratio $=24.225$ is rated as very significant $(\mathrm{p}<0.01)$.

Table 8. The regression of the amount of used mineral fertilizers and atmospheric precipitation during the vegetation period on maize yield

\begin{tabular}{|c|c|c|c|c|c|}
\hline \multirow[t]{2}{*}{$\mathrm{N}=40$} & \multicolumn{5}{|c|}{$\begin{array}{l}\text { Regression Summary for Dependent Variable: } \\
\text { Yield of maize } \\
\mathrm{R}=0.753 \\
\mathrm{R} \text { Square }=0.567 \\
\text { Adjusted R Square }=0.544 \\
\mathrm{~F}=24.225 \text { (Sig. }=0.000) \\
\text { Std. } \text { Error of the Estimate }=656.700\end{array}$} \\
\hline & $\mathrm{B}$ & Std. Error & Beta & $\mathrm{t}$ & Sig. \\
\hline Constant & 2486.872 & 435.984 & & 5.704 & 0.000 \\
\hline Used mineral fertilizers & 4.188 & 0.686 & 0.668 & 6.103 & 0.000 \\
\hline $\begin{array}{l}\text { Atmospheric precipitation during the } \\
\text { vegetation period }\end{array}$ & 4.234 & 0.995 & 0.446 & 4.254 & 0.000 \\
\hline
\end{tabular}

Source: Author`s calculations

\section{The analysis of yield of sunflower}

$$
\text { Sunflower }=1730.36+0.366 \text { mineral fertilizers }+0.383 \text { precipitation }
$$

The model of formation of sunflower yield indicates a very low estimation of the regression model $R^{2}=3.2 \%$, while the strength of connection between the observed variables $R=0.178$ shows that none of the observed factors of production has statistical significance $(\mathrm{p}>0.05)$. Also, the model cannot be accepted as statistically significant as indicated by the F-ratio = 0.607 rated as statistically insignificant $(\mathrm{p}>0.05)$. 
Table 9. The regression of the amount of used mineral fertilizers and atmospheric precipitation during the vegetation period on sunflower yield

\begin{tabular}{|l|c|c|c|c|c|}
\hline \multirow{5}{*}{$\mathrm{N}=40$} & \multicolumn{4}{l}{$\begin{array}{l}\text { Regression Summary for Dependent Variable: } \\
\text { Yield of sunflower } \\
\mathrm{R}=0.178 \\
\mathrm{R} \text { Square }=0.032 \\
\text { Adjusted R Square =-0.21 } \\
\mathrm{F}=0.607 \text { (Sig. }=0.505) \\
\text { Std. Error of the Estimate = 366.141 }\end{array}$} \\
\cline { 2 - 6 } & $\mathrm{B}$ & Std. Error & Beta & $\mathrm{T}$ & Sig. \\
\hline Constant & 1730.364 & 243.082 & & 7.118 & 0.000 \\
\hline Used mineral fertilizers & 0.366 & 0.383 & 0.157 & 0.956 & 0.345 \\
\hline $\begin{array}{l}\text { Atmospheric precipitation } \\
\text { vegetation period during the }\end{array}$ & 0.383 & 0.555 & 0.113 & 0.689 & 0.495 \\
\hline
\end{tabular}

Source: Author 's calculations

\section{The analysis of yield of soybean}

\section{Soybean $=1234.61-0.257$ mineral fertilizers +2.299 precipitation}

Rating of the regression model of the formation of soybean yields shows that the yield can be explained by the rated regression model with $R^{2}=21.6 \%$ and strength of connection between observed variables is $R=0.465$. The influence of independent variables on the yield of soybean is positive and highly statistically significant only in terms of quantity of atmospheric precipitation during the vegetation period $(\beta=0.448, \mathrm{p}<0.01)$, while the quantity of used mineral fertilizers has no statistical significance $(p>0.05)$. However, the model cannot be accepted in its entirety as a statistically significant, bearing in mind that also the F-ratio = 5.106 is rated as statistically insignificant $(\mathrm{p}>0.05)$.

Table 10. The regression of the amount of used mineral fertilizers and atmospheric precipitation during the vegetation period on soybean yield

\begin{tabular}{|c|c|c|c|c|c|}
\hline \multirow[t]{2}{*}{$\mathrm{N}=40$} & \multicolumn{5}{|c|}{$\begin{array}{l}\text { Regression Summary for Dependent Variable: } \\
\text { Yield of soybean } \\
\mathrm{R}=0.465 \\
\mathrm{R} \text { Square }=0.216 \\
\text { Adjusted } \mathrm{R} \text { Square }=0.174 \\
\mathrm{~F}=5.106 \text { (Sig. }=0.011) \\
\text { Std. } \text { Error of the Estimate }=498.554\end{array}$} \\
\hline & $\mathrm{B}$ & \begin{tabular}{|l|} 
Std. Error \\
\end{tabular} & Beta & $\mathrm{T}$ & Sig. \\
\hline Constant & 1234.613 & 330.991 & & 3.730 & 0.001 \\
\hline Used mineral fertilizers & -0.257 & 0.521 & -0.073 & -0.493 & 0.625 \\
\hline $\begin{array}{l}\text { Atmospheric precipitation during the } \\
\text { vegetation period }\end{array}$ & 2.299 & 0.756 & 0.448 & 3.043 & 0.004 \\
\hline
\end{tabular}

Source: Author's calculations

EP 2016 (63) 3 (817-833) 


\section{The analysis of yield of sugar beet}

\section{Sugar beet $=25770.29+16.875$ mineral fertilizers +26.907 precipitation}

The formation of sugar beet yields can be explained by the rated regression model with $R^{2}=33.1 \%$ and strength of connection between observed variables is $R=0.575$. The influence of independent variables on the realized yield of sugar beet is positive and statistically significant in both cases. In the case of used mineral fertilizers, the coefficient $\beta=0.421$ is rated to be statistically significant $(\mathrm{p}<0.05)$, also in the case of atmospheric precipitation during the vegetation period, the coefficient $\beta=0.462$ is rated as statistically significant $(p<0.05)$. The model can be accepted in its entirety because the F-ratio $=9.133$ is rated as statistically very significant $(\mathrm{p}<0.01)$.

Table 11. The regression of the amount of used mineral fertilizers and atmospheric precipitation during the vegetation period on sugar beet yield

\begin{tabular}{|l|l|l|l|c|c|}
\hline \multirow{5}{*}{$\mathrm{N}=40$} & \multicolumn{4}{l|}{$\begin{array}{l}\text { Regression Summary for Dependent Variable: } \\
\text { Yield of sugar beet } \\
\mathrm{R}=0.575 \\
\mathrm{R} \text { Square }=0.331\end{array}$} \\
& $\begin{array}{l}\text { Adjusted R Square =0.294 } \\
\text { F=9.133 (Sig. =0.001) } \\
\text { Std. Error of the Estimate =5227.083 }\end{array}$ \\
\cline { 2 - 6 } & $\mathrm{B}$ & Std. Error & Beta & $\mathrm{T}$ & Sig. \\
\hline Constant & 25770.299 & 3470.272 & & 7.426 & 0.000 \\
\hline Used mineral fertilizers & 16.875 & 5.462 & 0.421 & 3.090 & 0.004 \\
\hline $\begin{array}{l}\text { Atmospheric precipitation during the } \\
\text { vegetation period }\end{array}$ & 26.907 & 7.922 & 0.462 & 3.396 & 0.002 \\
\hline
\end{tabular}

Source: Author's calculations

On the basis of the correlation-regression analysis of observed variables, the following conclusions may be drawn:

The correlation-regression analysis has confirmed that there is a positive dependence of realized yields of maize on utilized mineral fertilizers, and significant positive correlation between yield and precipitation during the vegetation season. Due to the development of large above-ground biomass and grain weight, maize requires adequate amounts of nutrients in the soil, i.e. the shortages in plant nutrition often have very significant negative impact, both on the yield and on the quality of products, as confirmed in the numerous studies by following authors (Vučković, 1999; Glamočlija, 2004; Bogdanović et al., 2005; Živanović, 2012). Also, maize is a plant with strongly developed root system, but in critical periods is very sensitive to drought, especially in the period of flowering and fruit set (July and August), when in the ecological conditions in Vojvodina, the amount of atmospheric precipitation is at the minimum. The lack/absence of rainfall throughout the vegetation season, especially in the critical months, adversely affects the yield, which is confirmed by the analysis of interdependence between the yield and precipitation by research years, which is in 
accordance with the results of the researches performed by numerous local authors (Jevtić, 1986; Bogdanović et al., 1999; Glamočlija, 2006; Stojković et al., 2008).

- The correlation-regression analysis confirmed that the yield of wheat is under highly significant effect of the amount of used mineral fertilizer, which is confirmed in numerous previous studies (Jevtić, 1986; Vučković, 1999; Malešević et al., 2005; Stanković 2009; Popović, 2010). The reasons for these results are in the fact that wheat has a shallow root system that is very sensitive to the lack of the main elements of nutrition $(N, P, K)$, i.e. herbal assimilative to be entered by supplementary mineral fertilization of plants. At the same time, the analysis showed no statistical dependence between the wheat yield and atmospheric precipitation, i.e. precipitation during the vegetation period, although it is known that wheat is markedly hygrophilous species (Glamočlija, 2004). The reason for this statement is the fact that wheat goes through phases of intense water utilization in months of May and June, which, in the ecological conditions of Vojvodina, are the wettest months during the year.

- The correlation-regression analysis has confirmed that there is a positive dependence of realized yields of maize on utilized mineral fertilizers, and significant positive correlation between yield and precipitation during the vegetation season. Due to the development of large above-ground biomass and grain weight, maize requires adequate amounts of nutrients in the soil, i.e. the shortages in plant nutrition often have very significant negative impact, both on the yield and on the quality of products, as confirmed in the numerous studies by following authors (Vučković, 1999; Glamočlija, 2004; Bogdanović et al., 2005; Živanović, 2012). Also, maize is a plant with strongly developed root system, but in critical periods is very sensitive to drought, especially in the period of flowering and fruit set (July and August), when in the ecological conditions in Vojvodina, the amount of atmospheric precipitation is at the minimum. The lack/absence of rainfall throughout the vegetation season, especially in the critical months, adversely affects the yield, which is confirmed by the analysis of interdependence between the yield and precipitation by research years, which is in accordance with the results of the researches performed by numerous local authors (Jevtić, 1986; Bogdanović et al., 1999; Glamočlija, 2006; Stojković et al., 2008).

- The sunflower yield in the observed forty-year period showed no statistical dependence on the quantity of used mineral fertilizers. Sunflower has not reacted significantly to changes in the quantity of nutrients in the reporting period, so that lower or higher quantity of used mineral fertilizer NPK did not affect the significant variations in the grain yield. This can be explained by the fact that sunflower has a strong root system and deep and uses very well herbal assimilatives that have not been spent by the preceding crop. This refers especially to potassium and phosphorus (Glamočlija, 2006). Therefore, additional fertilization of plants should be based on the natural fertility of the soil, preceding crop, applied agro-technical measures and practices and actual needs of the plants. It can be seen that the sunflower expressed its xeromorphic character, so that the success of the production is not so much dependent on the amount and distribution of precipitation during the vegetation period in the studies area (Glamočlija, 2006). It can be concluded that the water regime in the ecological conditions of Vojvodina is satisfactory for the production of this field crop. 
- The amount and distribution of precipitation during the vegetation season had a very strong positive impact on the soybean yield. Soy is a plant species very sensitive to drought, especially in the period of flowering and fruit set which, depending on the varieties, lasts from 50 to 70 days. In order to achieve high and stable yields of grain and soybean aboveground mass, it is necessary that in the critical period of development (the second half of June, July and August) there is about 250-300 mm of rainfall evenly distributed (Glamočlija, 2004; Bošnjak, Pejić, 2004). In addition to the soil drought, soy reacts extremely strongly to air drought. In contrast, due to a strong root system, soy exceptionally adopts phosphorus and potassium from the deeper soil layers, as nitrogen collector, soy grows equally well in conditions of lower soil fertility, and natural, as well as slight supplementary fertilization of plants. Due to the aforementioned facts, the analysis showed no significance of used mineral fertilizers on the grain yields in the reporting period, which has been established in the research of Glamočlija et al. (1998) and Đukić, V. et al. (2009).

- The correlation and regression analysis showed a statistically significant positive correlation between the yield of sugar beet and observed production factors (used quantity of mineral fertilizers and atmospheric precipitation during the vegetation period). Sugar beet is a major consumer of the main nutrients of the diet which was confirmed by this study, i.e. a significant reduction in yield due to lack of abundant plant nutrients is established, as confirmed in the published research results (Lazović, 1984; Glamočlija, 1990; Jaćimović et al., 2006; Bojović, 2014). Also, this plant species is relatively drought resistant, although in critical periods (the phase of the secondary roots thickening - July, the first half of August) due to water deficit, significant increase of sugar beet is missing, which is why the analysis of the dependence of sugar beet yield on the atmospheric precipitation showed significance (Maksimović, Dragović, 2002; Grujančić et al., 2008; Maksimović et al., 2010; Bojović, 2014). However, in dry years with lower root yield, sugar beet has a significantly higher digestion (total sugar content of the root), because the lack of water is partially compensated by increased synthesis of sucrose.

\section{Conclusion}

Based on the results of performed research it can be concluded that the yields of major field crops realized on family farms in the region of Vojvodina are significantly lower than yields in developed countries, resulting in the reduction in their economic efficiency and rationality of operation. The reasons for this situation are in the fact that, despite the favourable natural conditions, the agricultural production in the region is characterized by unfavourable property structure of family farms, the heavy dependence of realized yield on the precipitation and relatively low utilization of mineral fertilizers.

The correlation and regression analysis showed that the realized grain yields of major field crops on family farms in the region of Vojvodina, in the forty-year study period, the statistically significant or very significant impact is determined for the application of mineral fertilizers and atmospheric precipitation during the vegetation period. The obtained results show that with the increasing intensity of production, primarily through rational mineral fertilization based on the results of analysis of soil fertility parameters and received recommendations 
from expert advisory services, as well as through the application of irrigation, especially during critical periods of the vegetation season, the yields of major field crops on family farms can increase significantly, and hence their competitiveness. It is therefore necessary that the agricultural policy measures are defined at the national level, which would provide the necessary financial and technical support to those family farms that are willing to invest in the intensification of production and improve their economic performance.

\section{Literature}

1. Bogdanović, B., Čapelja, B., Radojičić, S. (1999): Proizvodnja semena kukuruza, Zbornik radova, Naučni institut za ratarstvo i povrtarstvo, Novi Sad, pp. 265-269.

2. Bogdanović D., Ubović, M., Malešević, M. (2005): Metode za utvrđivanje potreba biljaka za azotom, Azot - agrohemijski, agrotehnički, fiziološki i ekološki aspekti, Novi Sad, pp. 154-188.

3. Bojović R. (2014): Morfološke i proizvodne osobine genotipova šećerne repe u uslovima intenzivne ishrane biljaka, Doktorska disertacija, Poljoprivredni fakultet, Beograd.

4. Bošnjak D., Rodić V. (2010): Komparativna analiza troškova proizvodnje osnovnih ratarskih useva u Vojvodini, Ekonomika poljoprivrede, vol. 57, no. 2, pp. 233-243, Institut za ekonomiku poljoprivrede Beograd, Republika Srbija.

5. Bošnjak, Đ., Pejić, B. (2004): Realizacija racionalnog zalivnog režima kukuruza, Zbornik radova vol. 22, Naučni institut za ratarstvo i povrtarstvo, Novi Sad, pp. 167178.

6. Đukić, V., Đorđević, V., Popović V., Kostić M., Ilić, A., Dozet, G. (2009): Uticaj đubrenja na prinos soje, Zbornik radova, vol. 46, no 1, Naučni institut za ratarstvo i povrtarstvo, Novi Sad, pp. 17-23.

7. Glamočlija, Đ. (1990): Uticaj jačine đubriva i gustine useva na prinos i kvalitet šećerne repe, Zbornik radova „IV zimski seminar agronoma-ratara Srbije“, Vrnjačka Banja, pp. 148-158.

8. Glamočlija, Đ., Nedić, M., Lazarević J. (1998): Effects of micro and macroelements on soyabean yield and protein content, II Balkan Symposiumon Field Crops, Ecology, Physiology, and Curtural Practices, Vol. 2.

9. Glamočlija, Đ. (2004): Posebno ratarstvo - žita i zrnene mahunarke, Draganić, Beograd.

10. Glamočlija, Đ. (2006): Specijalno ratarstvo, Poljoprivredni fakultet, Beograd.

11. Gujaničić, T., Glamočlija, Đ., Maletić R., Savić J. (2008): Proizvodnja šećerne repe u uslovima intenzivne ishrane biljaka i navodnjavanja useva, Arhiv za poljoprivredne nauke, no. 69, pp. 69-78.

12. Jaćimović, G., Marinković, B., Crnoborac, J. (2006): Prinos rafinisanog šećera $u$ zavisnosti od nivoa đubrenja šećerne repe, Savremena poljoprivreda, vol. 54, no. 3-4, pp. 285-289,Novi Sad.

13. Jevtić, S (1986): Kukuruz, Narodna knjiga, Beograd.

EP 2016 (63) 3 (817-833) 
14. Kresović M. (2010): Đubrenje ratarskih i povrtarskih kultura I deo Metode za određivanje potrebnih količina đubriva, Poljoprivredni fakultet Beograd.

15. Lazović, D. (1984): Uticaj rastućih količina NPK na dinamiku stvaranja prinosa šećerne repe $i$ šećera $i$ iznošenje mineralnih materija prinosom od šećernate i prinosne sorte šećerne repe, Doktorska disertacija, Poljoprivedni fakultet, Novi Sad.

16. Malešević, M., Crnoborac, J., Kastori, R. (2005): Primena azotnih đubriva i njihov uticaj na prinos i kvalitet proizvoda, Azot-Agrotehnički, fiziološki i ekološki aspekti, Novi Sad, pp. 233-267.

17. Maksimović L., Dragović, S. (2002): Efekat navodnjavanja šećerne repe u različitim ekološkim uslovima gajenja, Zbornik radova Instituta za ratarstvo i povrtarstvo no. 36, Naučni institut za ratarstvo i povrtarstvo, Novi Sad, pp. 43-56.

18. Maksimović L., Babović, J., Carić M., Milić, S. (2010): Ekonomski efekti navodnjavanja $i$ đubrenja u proizvodnji šećerne repe, Economics of Agriculture, vol. 57, no. 4, pp. 611623, Beograd.

19. Pejić, B. (2008): Specifičnosti proizvodnje ratarskih i povrtarskih biljnih vrsta u uslovima navodnjavanja, Poljoprivredni fakultet, Novi Sad.

20. Popović V. (2010): Agrotehnički i agroekološki uticaji na proizvodnju semena pšenice, kukuruza i soje, Doktorska disertacija, Poljoprivredni fakultet, Beograd.

21. Stanković, S. (2009): Uticaj azota na proizvodnju pšenice na različitim tipovima zemljišta, Doktorska disertacija, Poljoprivredni fakultet, Beograd.

22. Stojaković, M., Jocković, Đ., Ivanović, M., Bekavac, G., Nastasić, A., Simić, D., Stojaković, Ž. (2008): Prinos zrna NS hibrida kukuruza u proizvodnim rejonima Srbije, Zbornik radova, vol. 45, no. 2, Naučni institut za ratarstvo i povrtarstvo, Novi Sad, pp. 67-79.

23. Tabaković, M. (2012): Uticaj vremenskih uslova, zemljišta i genotipske kombinacije na osobine hibridnog semena kukuruza, Doktorska disertacija, Poljoprivredni fakultet, Beograd.

24.Živanović, Lj. (2012): Uticaj tipa zemljišta i količine azota na produktivnost hibrida kukuruza različitih FAO grupa zrenja, Doktorska disertacija, Poljoprivredni fakultet, Beograd. 


\section{UTICAJ MINERALNE ISHRANE I ATMOSFERSKIH PADAVINA NA PRINOS RATARSKIH USEVA PORODIČNIH GAZDINSTAVA ${ }^{3}$}

\section{Mihajlo Munćan ${ }^{4}$}

\section{Rezime}

Ratarska proizvodnja, kao najvažnija grana biljne proizvodnje Republike Srbije, u periodu 2002-2011. godina, odvijala se prosečno na preko 2,7 miliona hektara, od čega se $82,7 \%$ ove proizvodnje odvija na posedima porodičnih gazdinstava. Otuda su i predmet istraživanja u ovom radu ostvarni prinosi osnovnih ratrskih useva na porodičnim gazdinstvima regiona Vojvodine uperiodu 1972-2011. godina. Osnovni cilj istraživanjaje ispitivanjemeđuzavisnosti potrošnje mineralnih đubriva i atmosferskih padavina u vegetacionom periodu i ostvarenih prinosa osnovnih ratarskih useva na porodičnim gazdinstvima u posmatranom periodu. Radi potvrdivanja zavisnosti i utvrdivanja oblika zavisnosti ostvarenih prinosa od ispitivanih varijabli primenjena je regresiona analiza. Dobijeni rezultati pokazali su da su osnovni ograničavajući faktori za dobijanje visokih $i$ stabilnih prinosa ratarskih useva neadekvatna upotreba mineralnih đubriva i nedostatak atmosferskih padavina u vegetacionom periodu.

Ključne reči: međuzavisnost, mineralna đubriva, atmosferske padavine, ratarski usev, porodično gazdinstvo

3 Rad je rezultat istraživanja na projektu „Ruralno tržište rada i ruralna ekonomija Srbije diverzifikacija dohotka i smanjenje ruralnog siromaštva“, broj 179028, finansiranom od strane Ministarstva prosvete, nauke i tehnološkog razvoja Republike Srbije

4 Docent Dr Mihajlo Munćan, saradnik, Univerzitet u Beogradu, Poljoprivredni fakultet, Nemanjina ulica br. 6, 11080 Zemun, Republika Srbija, Telefon +381 11 4413406, E-mail: mmuncan@agrif.bg.ac.rs; 